\title{
Polymorphisms in $\alpha$ - and $\beta$-Adrenergic Receptor Genes, Hypertension, and Obstructive Sleep Apnea: The Skaraborg Sleep Study
}

\author{
Kristina Bengtsson Boström, ${ }^{1,2,3}$ Jan Hedner, ${ }^{4}$ Ludger Grote, ${ }^{4}$ Olle Melander, ${ }^{2}$ \\ Fredrik von Wowern, ${ }^{2}$ Lennart Råstam, ${ }^{3}$ Leif Groop, ${ }^{2}$ and Ulf Lindblad ${ }^{3,5,6}$ \\ ${ }^{1}$ RÆD Centre Skaraborg Primary Care, Storgatan 18, 54130 Skövde, Sweden \\ ${ }^{2}$ Department of Clinical Sciences, Diabetes and Endocrinology, Malmö University Hospital, Lund University, 20502 Malmö, Sweden \\ ${ }^{3}$ Department of Clinical Sciences, Community Medicine, Malmö University Hospital, Lund University, 20502 Malmö, Sweden \\ ${ }^{4}$ Sleep Laboratory, The Sahlgrenska Academy, University of Gothenburg, 41345 Gothenburg, Sweden \\ ${ }^{5}$ Department of Public Health and Community Medicine/Primary Health Care, The Sahlgrenska Academy, University of Gothenburg, \\ P.O. Box 400, 40530 Göteborg, Sweden \\ ${ }^{6}$ Skaraborg Institute, Stationsgatan 12, 54130 Skövde, Sweden
}

Correspondence should be addressed to Kristina Bengtsson Boström, kristina.a.bengtsson@vgregion.se

Received 31 December 2009; Accepted 5 March 2010

Academic Editor: Tomohiro Katsuya

Copyright ( 92010 Kristina Bengtsson Boström et al. This is an open access article distributed under the Creative Commons Attribution License, which permits unrestricted use, distribution, and reproduction in any medium, provided the original work is properly cited.

The sympathetic nervous system and the adrenergic receptors play an important role in regulation of blood pressure. This study explored the associations between functional polymorphisms of the $\alpha_{2 \mathrm{~B}^{-}}, \beta_{1^{-}}$, and $\beta_{2}$-adrenergic receptor genes and obstructive sleep apnea (OSA) in hypertensive patients and hypertension in patients with OSA in a populationbased sample of 157 hypertensive patients and 181 healthy control subjects. Only the Arg389Gly polymorphism of the $\beta_{1}$-adrenergic receptor gene was associated with increased risk for mild OSA in hypertensive patients (Arg/Arg versus Gly/Arg/Gly/Gly, 2.1, 95\% CI, 1.02-4.7). Hypertensive men carrying the Arg389Arg genotype had higher crude and age-adjusted AHI than carriers of the Arg389Gly/Gly389Gly genotypes. When adjusted also for BMI this difference became borderline significant. This difference was not observed in women. The risk of hypertension in mild OSA was associated with increasing number of Arg-alleles (Arg/Arg OR 5.4, 95\% CI 1.4-21.2).

\section{Introduction}

Obstructive sleep apnea (OSA) is a disorder characterized by upper airway collapse and is common in middle-aged adults [1]. OSA often leads to hypoxia and activation of the sympathetic nervous system $[2,3]$ which might lead to adverse metabolic reactions and high blood pressure $[4,5]$. OSA has in humans been associated with hypertension $[6,7]$ and cardiovascular complications $[8,9]$. In an earlier study of a population-based sample of hypertensive patients and normotensive controls from primary care in Sweden, OSA was found to be more prevalent in hypertensive patients, specifically in male patients compared to controls, $83 \%$ versus $64 \%$ ( $58 \%$ versus $49 \%$ in females) when OSA was defined as apnea/hypopnea index $(\mathrm{AHI}) \geq 10$ events per hour and $47 \%$ versus $25 \%$ (26\% versus $24 \%$ in females) when OSA was defined as AHI $\geq 30$ events per hour [7].

The sympathetic nervous system plays an important role in regulation of blood pressure and the adrenergic receptors are important components of this system. The aim of this study was to explore the associations between functional polymorphisms of the $\alpha_{2 B^{-}}, \beta_{1^{-}}$, and $\beta_{2}$-adrenergic receptor genes and occurrence of OSA in hypertensive patients and occurrence of hypertension in patients with OSA in a population-based sample.

The $\alpha_{2 \mathrm{~A}}$-adrenergic receptor and the $\alpha_{2 \mathrm{~B}}$-adrenergic receptor are expressed in the central nervous system. Blood pressure is regulated by the opposing action of these 
receptors upon agonist binding. The $\alpha_{2 \mathrm{~A}}$-adrenergic receptor has an inhibiting effect on the sympathetic outflow while the $\alpha_{2 \mathrm{~B}}$-adrenergic receptor has an excitatory effect [10]. The $\alpha_{2 \mathrm{~B}}$-adrenergic receptor gene is located on chromosome 2 in a region where several genome scans, including one from the population in the current study [11], have found linkage to blood pressure variation and hypertension [1214]. In the third intracellular loop of the receptor, in an area of importance in downregulation, there is a polymorphism consisting of either an insertion (I) or a deletion (D) of three amino acids at positions 301-303. Earlier studies have shown that the deletion variant confers an increased activity in the sympathetic nervous system [15] and that it is associated with hypertension in the current and other populations $[16,17]$.

The $\beta_{1}$-adrenergic receptor is expressed in cardiac myocytes [18] and upon agonist binding it confers excitatory reactions in the myocyte leading to higher cardiac output through increased cardiac inotropy and chronotropy.

The $\beta_{1}$-adrenergic receptor gene on chromosome 10 harbors two polymorphisms with functional properties. The Ser49Gly, located in the extra cellular portion of the receptor, has been associated with variations in resting heart rate in a dose dependent way [19]. The other polymorphism, Arg389Gly, is located in the intracellular cytoplasmic tail of the receptor near the seventh transmembrane region, where the stimulatory G-protein probably binds. In vitro studies have shown that the Arg389 variant mediates a higher isoproterenol stimulated adenylate cyclase activity than the Gly389 variant [20]. Homozygous carriers of Arg389 have been shown to have a higher risk for hypertension and higher diastolic blood pressure levels and heart frequency than carriers of the other genotypes in the current population [21] and a minor influence on both systolic and diastolic blood pressure in a larger population [22]. The homozygous Arg389 carriers have also been shown to have a greater blood pressure lowering response to atenolol [23] and metoprolol [24] compared with the homozygous Gly389 carriers strengthening its functional importance in cardiovascular regulation. Whether the polymorphism is associated with higher risk for cardiovascular complications is not clear $[25,26]$. Recently, it has been shown that the Arg389Gly polymorphism can modify the beneficial effect of continuous airway pressure [27].

The $\beta_{2}$-adrenergic receptor is expressed in most arteries in the body and in the heart and also in the respiratory tract. Upon agonist binding it elicits dilation of the arteries and bronchi. The $\beta_{2}$-adrenergic receptor gene is located on chromosome 5 in an area where already in 1996 genetic variation was found to be associated with hypertension [28]. Linkage to blood pressure levels has been found in genome wide scans [29] and subsequent fine mapping has revealed association between hypertension and the $\beta_{2}$ adrenergic receptor gene variants [30] in the cytoplasmic tail of the receptor. Two polymorphisms, the Arg16Gly and Gln27Glu, have been found in vitro to confer different degree of downregulation of the receptor [31]. Studies on humans have given conflicting results possibly because the two polymorphisms have different properties and are in linkage disequilibrium with each other [32]. In the Ectim and PEGASE studies there was no association between the polymorphisms of the receptor and myocardial infarction [33]. In studies of Scandinavian subjects, the Arg16 and Gln27 variants were found to be associated with an increased risk of hypertension [34] and with hypertension associated with type 2 diabetes [35].

\section{Subjects and Methods}

2.1. Study Population. The Skaraborg Hypertension and Diabetes Project cohort have previously been described in detail [36]. This sample comprises the majority of patients with hypertension and/or type 2 diabetes $(n=1149)$ in the local community of Skara investigated in 19921993 and an age-stratified, random sample from 40 years of age from Skara population $(n=1109)$ that was investigated in 1993-1994 [37]. In 2000, a random sample of hypertensive and normotensive men and women from 40 to 64 years at the baseline investigations was drawn from the previous cohorts. The diagnosis of hypertension was based upon at least three consecutive diastolic blood pressure measurements $\geq 90 \mathrm{mmHg}$ diastolic blood pressure (DBP) according to the current National Guidelines [38, 39] or ongoing antihypertensive treatment at baseline. Most hypertensive subjects in the present study (at least $85 \%$ ) were already diagnosed according to the criteria used before 1989 ( $\geq 160 / 95$ mmHg, WHO, 1989 [40]) and had ongoing antihypertensive treatment. Normotension was defined as a systolic blood pressure $(\mathrm{SPB})<160 \mathrm{mmHg}$ and a DBP $<90 \mathrm{mmHg}$ and no antihypertensive medication. Type 2 diabetes was diagnosed according to the current WHO recommendations [41] in 21 hypertensive patients. A full-night polysomnography (PSG) at home was performed in 344 subjects, 161 patients with hypertension, and 181 individuals without hypertension. The local ethics committee approved the study and written informed consent was obtained from all the participants.

2.2. Study Procedure. At baseline 1992-1994 all subjects were surveyed for cardiovascular disease (CVD) risk factors using a previously published protocol [42]. Sleep studies were conducted during 2000-2002. A specially trained study nurse performed the basic investigations. The blood pressure was measured with Tricuff [43] in the supine position with a sphygmomanometer after 5 minutes of rest. A standardised interview on medical history and medications was performed and a questionnaire on sleep quality, daytime sleepiness, and symptoms of depression was administered [44]. Height was measured to the nearest centimetre and weight to the nearest $0.1 \mathrm{~kg}$ and body mass index (BMI) was calculated. A full night PSG recording was performed in the subjects' home using a portable Embla-A10 polysomngraphy system (Flaga, Reykjavik, Iceland). Each recording included three-channel electroencephalography (EEG, $\mathrm{C}_{4} / \mathrm{A}_{1}, \mathrm{C}_{3} / \mathrm{A}_{2}$ ), two-channel electrooculography, and one-channel submental electromyography (EMG). Limb movements were monitored by tibial surface electrodes. Ventilatory monitoring included oxygen saturation $\left(\mathrm{SaO}_{2}\right)$ by an oximeter probe, 
respiratory movements by chest and abdominal belts, nasal and oral airflow by thermistor and nasal pressure by pressure sensors. Two cotrained staff members manually scored the recordings according to a validated scoring manual [45]. A successful PSG required a minimum of 4 hours sleeping time including at least one REM-sleep period. The number of apnea/hypopnea events per hour of sleep (AHI) was used to dichotomise subjects into two groups, one with a cutoff level of 10 events per hour (mild OSA, OSA10, AHI $\geq 10$ events per hour) and one with a cutoff level of 30 events per hour (severe OSA, OSA30, AHI $\geq 30$ events per hour). Separate statistical analyses were undertaken to compare the two groups with the control subjects (those with AHI $<10$ and $<30$ events per hour, resp.).

2.3. Genotyping. High molecular weight DNA was extracted from blood leukocytes according to standard techniques [46] and used as template in all polymerase chain reactions (PCRs). The genotyping procedures have been described elsewhere $[16,35,47]$. The PCR conditions and digestion conditions in the restriction fragment length polymorphism (RFLP) reactions are shown in Table 1.

2.4. Statistical Methods. Hypertensive and normotensive subjects were analysed separately. Continuous variables are presented as means \pm standard deviation (SD) and discrete variables as frequencies (\%). Differences between means were tested by ANCOVA. Differences in proportions were tested by $\chi^{2}$-test and by logistic regression. Confounding from age and sex was accounted for by multivariate analyses or by stratification. Multiple logistic regressions were performed with mild OSA (OSA10) and severe OSA (OSA30) as the dependent variable and with age, sex, BMI and the $\alpha_{2 \mathrm{~B}}$-adrenergic receptor, $\beta_{1}$ - and $\beta_{2}$-adrenergic receptor polymorphisms as independent variables. Associations were expressed as odds ratio (OR) with 95 per cent confidence interval $(95 \% \mathrm{CI})$. For the $\alpha_{2 \mathrm{~B}}$-adrenergic receptor gene the II genotype was used as reference in the comparison with the ID and DD genotypes. For the $\beta_{1}$-adrenergic receptor gene the combination of Ser49Gly and Gly49Gly was used as a reference and compared with the Ser49Ser genotype. The combination of Gly389Gly and Arg389Gly genotypes was used as reference and compared with the Arg389Arg genotype. Finally, for the $\beta_{2}$-adrenergic receptor gene the Gly16Gly and Glu27Glu genotypes were used as references compared with the Arg16Gly and Arg16Arg and the Gln27Glu and Gln27Gln genotypes, respectively. Analyses were carried out using SPSS Base system for Macintosh 11.0 (Chicago, SPSS Inc.). All statistical tests were two sided. $P$-values less than .05 were considered statistically significant.

\section{Results}

The clinical characteristics of the subjects are shown in Table 2. As expected hypertensive patients had higher systolic and diastolic blood pressure but were also older and had higher BMI than normotensive subjects. AHI was higher in hypertensive men but did not differ between hypertensive and normotensive women. The observed genotype frequencies were all in Hardy Weinberg equilibrium.

3.1. The $\alpha_{2 B}$-Adrenergic Receptor. The genotype frequencies of the $\alpha_{2 \mathrm{~B}}$-adrenergic receptor gene were $15 \%$ for DD genotype, $51 \%$ for ID genotype, and $34 \%$ for the II genotype. There was no statistical difference in genotype or allele frequencies of the 301-303 I/D polymorphism in hypertensive patients with or without OSA (Table 3 ) or in normotensive controls (data not shown).

3.2. The $\beta_{1}$-Adrenergic Receptor. The Arg389Arg genotype of the $\beta_{1}$-adrenergic receptor gene was more common in male hypertensive patients with mild OSA than in those without mild OSA (Table 3 ). There was a similar trend in hypertensive females and in hypertensive males with severe OSA. Among the 62 analyzed men there was no one with OSA carrying the Gly389Gly genotype (Table 3). In a recessive model comparing Arg389Arg to Arg389Gly and Gly389Gly there was a significant association with mild OSA in hypertensive subjects, OR 2.3 (95\% CI 1.10-4.87), $P=$ .027 , crude and when adjusted for age and sex OR $2.3(95 \%$ CI 1.09-4.96), $P=.029$ and still significant when adjusted also for BMI OR 2.1 (95\% CI 1.02-4.71), $P=.045$. In sex specific analysis the patterns were very similar in men and women; however, neither crude nor adjusted models turned out significant. In the full model we found OR 3.4 (95\% CI $0.85-13.40), P=.085$ in men, and 2.26 (95\% CI 0.85-5.99), $P=.102$ in women, respectively. Hypertensive men carrying the Arg389Arg genotype had higher crude and age-adjusted AHI than carriers of the Arg389Gly/Gly389Gly genotypes. When adjusted also for BMI this difference became borderline significant. This difference was not observed in women (Table 4). There was also a dose dependent increase in AHI according to genotype being the lowest in Gly389Gly carriers increasing in the Arg389Gly and the highest in Arg389Arg carriers, significant in all men $(15.0 \pm 13.7,24.3 \pm 18.5$ and $32.3 \pm 26.2$ events per hour, $P=.017)$. In the subgroups of men with and without hypertension AHI showed a similar increasing trend, 4.0 (one subject), $27.2 \pm 20.1$ and $39.5 \pm$ 27.7 events per hour, $P=.065$ and $16.1 \pm 13.9,21.8 \pm 16.9$, and $25.9 \pm 23.4$ events per hour, $P=.33$, respectively. In women no such trend was observed $(28.8 \pm 27.5,22.9 \pm 25.3$, and $23.7 \pm 23.1$ events per hour $P=.72$ ).

In analysis including both patients with hypertension and normotensive controls subjects the frequency of hypertension versus normotension differed significantly between the different genotype carriers in subjects with mild OSA (Table 5). When using the number of Arg389 alleles as an approximately linear variable the age and BMI adjusted OR for hypertension in patients with mild OSA were for one Arg389 allele 4.8 (95\% CI 1.2-19.3), $P=.028$ and for two Arg389 alleles 5.4 (95\% CI 1.4-21.2), $P=.015$. A test for trend adjusted for age, sex, and BMI also showed an increased OR for hypertension with increasing number of Arg389 alleles, OR 1.6, 95\% CI 1.003-2.5, $P=.048$.

3.3. The $\beta_{2}$-Adrenergic Receptor. Neither of the investigated polymorphisms (Arg16Gly or Gln27Glu) was associated with 
TABLE 1: PCR and digestion conditions for genotyping of the the $\alpha_{2 B^{-}}, \beta_{1^{-}}$, and the $\beta_{2}$-adrenergic receptor gene polymorphisms.

\begin{tabular}{|c|c|c|c|c|c|c|c|c|c|}
\hline \multirow{2}{*}{$\begin{array}{l}\text { Gene/polymorphism } \\
\mathrm{N} \text { successfully } \\
\text { genotyped }\end{array}$} & \multirow{2}{*}{$\begin{array}{l}\text { Forward (sense) primer sequence } \\
\text { Reverse (antisense) primer sequence }\end{array}$} & \multicolumn{5}{|c|}{ PCR conditions } & \multicolumn{2}{|c|}{ RFLP } & \multirow{2}{*}{$\begin{array}{c}\mathrm{Gel}^{\ddagger \neq} \\
\%\end{array}$} \\
\hline & & Size (bp) & $\begin{array}{c}\text { Annealing } \\
T\left({ }^{\circ} \mathrm{C}\right)\end{array}$ & $\begin{array}{l}\text { Extension } \\
\text { time }(\mathrm{s})\end{array}$ & $\begin{array}{c}\mathrm{Mg}^{2}+ \\
\mathrm{mmol} / \mathrm{L}\end{array}$ & Cycles & Enzyme & $\begin{array}{l}\text { Time } \\
(\mathrm{h})\end{array}$ & \\
\hline \multicolumn{10}{|l|}{338 A2BAR } \\
\hline I/D 301-303 & $\begin{array}{l}\text { 5'-AGGGTGTTTGTGGGGCATCT } \\
\text { 5'-CAAGCTGAGGCCGGAGACACT }\end{array}$ & $112 / 103$ & 72 & 30 & 1.5 & 33 & - & & 3 \\
\hline \multicolumn{10}{|l|}{$337 * \mathrm{~B} 1 \mathrm{AR}$} \\
\hline Ser49Gly & $\begin{array}{c}\text { 5' -CCGGGCTTCTGGGGTGTTCC } \\
\text { 5'-GGCGAGGTGATGGCGAGGTAGC }\end{array}$ & 562 & 64 & 30 & 1.5 & 35 & EcoO109I & 3 & 2 \\
\hline Arg389Gly & $\begin{array}{l}5^{\prime} \text {-CGCTCTGCTGGCTGCCCTTCTTCC } \\
5^{\prime} \text {-TGGGCTTCGAGTTCACCTGCTATC }\end{array}$ & 530 & 64 & 30 & 1.5 & 33 & $B c g I$ & 3 & 2 \\
\hline \multicolumn{10}{|l|}{338 B2AR } \\
\hline Arg16Gly & $\begin{array}{c}5^{\prime} \text {-CGCCTTCTTGCTGGCACGCAAT ** } \\
\text { 5' -CCAGTGAAGTGATGAAGTAGTT }\end{array}$ & 203 & 60 & 30 & 1.5 & 30 & $\mathrm{BsrDl}$ & 2 & 4.5 \\
\hline Gln27Glu & $\begin{array}{c}5^{\prime} \text {-CCGGACCACGACGTCACCCAG }{ }^{* * *} \\
5^{\prime} \text {-CCAGTGAAGTGATGAAGTAGTT }\end{array}$ & 169 & 60 & 30 & 1.5 & 30 & BstNl & 2 & 4.5 \\
\hline
\end{tabular}

A2BAR: $\alpha_{2 \mathrm{~B}}$-adrenergic receptor gene; B1AR: $\beta_{1}$-adrenergic receptor; B2AR: $\beta_{2}$-adrenergic receptor; Ag: agarose; bp: base pair.

* The genotyping failed in one individual.

$* *$ The underlined nucleotide is a mismatch to create a $B s r D l$ recognition site in case of the Gly16-allele.

$* * *$ The underlined nucleotide is a mismatch to create a BstNl recognition site in case of the Glu27-allele.

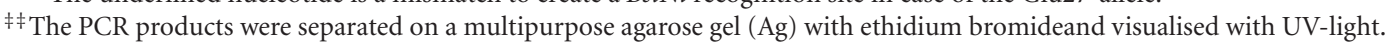

TABLE 2: Clinical characteristics in normotensive and hypertensive men and women.

\begin{tabular}{|c|c|c|c|c|c|}
\hline \multirow[b]{2}{*}{ Variables } & \multicolumn{2}{|c|}{ Normotensive subjects } & \multicolumn{2}{|c|}{ Patients with hypertension } & \multirow[b]{2}{*}{$P$} \\
\hline & Mean & $(\mathrm{SD})$ & Mean & $(\mathrm{SD})$ & \\
\hline $\operatorname{Men}(n)$ & 96 & & 74 & & \\
\hline Age (years) & 60 & $(6.3)$ & 62 & $(6.2)$ & .008 \\
\hline Systolic blood pressure (mmHg) & 131 & $(13.2)$ & 148 & $(15.7)$ & $<.001$ \\
\hline Diastolic blood pressure $(\mathrm{mmHg})$ & 77 & $(7.5)$ & 84 & $(6.7)$ & $<.001$ \\
\hline Heart rate (beats per minute) & 68 & $(8.3)$ & 68 & $(8.2)$ & .653 \\
\hline AHI (events per hour) & 23 & $(20.4)$ & 34 & $(25.6)$ & .005 \\
\hline Body mass index $\left(\mathrm{kg} / \mathrm{m}^{2}\right)$ & 26.8 & $(3.0)$ & 29.5 & $(4.6)$ & $<.001$ \\
\hline Women $(n)$ & 85 & & 83 & & \\
\hline Age (years) & 60 & $(7.1)$ & 64 & $(5.7)$ & $<.001$ \\
\hline Systolic blood pressure (mmHg) & 132 & $(14.8)$ & 150 & $(16.8)$ & $<.001$ \\
\hline Diastolic blood pressure $(\mathrm{mmHg})$ & 75 & $(7.5)$ & 83 & $(8.0)$ & $<.001$ \\
\hline Heart rate (beats per minute) & 70 & $(8.7)$ & 69 & $(9.0)$ & .944 \\
\hline AHI (events per hour) & 22 & $(26.0)$ & 25 & $(22.2)$ & .655 \\
\hline Body mass index $\left(\mathrm{kg} / \mathrm{m}^{2}\right)$ & 28.1 & $(4.8)$ & 30.3 & $(5.7)$ & .006 \\
\hline
\end{tabular}

Data are mean (SD). Differences in means were analysed by general linear models with adjustment for age. AHI: apnea/hypopnea index.

increased risk of OSA in hypertensive subjects or with hypertension in patients with OSA (data not shown).

\section{Discussion}

We describe an association between the Arg389Arg genotype of the $\beta_{1}$-adrenergic receptor gene and OSA in hypertensive patients. Furthermore, occurrence of hypertension increased in subjects with mild OSA with increasing number of Arg389 alleles. The Arg389Arg genotype carriers had a borderline significantly higher AHI than the Arg389Gly/Gly389Gly carriers when adjusted for age and BMI. While the current study was designed to investigate the risk of OSA in patients with hypertension, the results showing that the risk of hypertension in subjects with mild OSA was associated with the Arg389 allele are in accordance with what have been previously published on association between hypertension and the Arg389Gly polymorphism [21].

The $\beta_{1}$-adrenergic receptor is important in the adrenergic activation of the heart by increasing both the inotropic and 
TABLE 3: Genotype frequencies of adrenergic receptor genes: $\alpha_{2 B}$-adrenergic I/D, the $\beta_{1}$ Ser49Gly and Gly389Arg, and the $\beta_{2}$ Gly 16 Arg and Gln27Glu polymorphisms in hypertensive patients with and without mild (panel A) and severe (panel B) obstructive sleep apnoea (OSA).

\begin{tabular}{|c|c|c|c|c|c|c|c|}
\hline A & \multicolumn{3}{|c|}{ Patients with mild OSA } & \multicolumn{3}{|c|}{ Patients without mild OSA } & \multirow[t]{2}{*}{$P$} \\
\hline \multicolumn{7}{|c|}{$\alpha_{2 \mathrm{~B}}$-adrenergic receptor gene I/D polymorphism $(n=157)$} & \\
\hline Genotype & II & ID & $\mathrm{DD}$ & II & ID & $\mathrm{DD}$ & \\
\hline Men OSA10 $(n=74)$ & $18(28.6)$ & $32(50.8)$ & $13(20.6)$ & $5(41.7)$ & $6(50.0)$ & $1(8.3)$ & .50 \\
\hline Women OSA10 $(n=83)$ & $20(35.7)$ & $27(48.2)$ & $9(16.1)$ & $9(34.6)$ & $11(42.3)$ & $6(23.1)$ & .73 \\
\hline \multicolumn{8}{|c|}{$\beta_{1}$ adrenergic receptor gene Ser49Gly and Gly389Arg polymorphisms $(n=156)$} \\
\hline Genotype (Ser49Gly) & $\mathrm{S} / \mathrm{S}$ & S/G & G/G & S/S & S/G & $\mathrm{G} / \mathrm{G}$ & $P$ \\
\hline Men OSA10 $(n=74)$ & $37(59.7)$ & $24(38.7)$ & $1(1.6)$ & $9(75.0)$ & $3(25.0)$ & $0(0.0)$ & .58 \\
\hline Women OSA10 $(n=82)$ & $39(69.6)$ & $12(21.4)$ & $5(8.9)$ & $20(76.9)$ & $6(23.1)$ & $0(0.0)$ & .29 \\
\hline Genotype(Gly389Arg) & G/G & G/A & $\mathrm{A} / \mathrm{A}$ & G/G & G/A & $\mathrm{A} / \mathrm{A}$ & $P$ \\
\hline Men OSA10 $(n=74)$ & $0(0.0)$ & $23(37.1)$ & $39(62.9)$ & $1(8.3)$ & $6(50.0)$ & $5(41.7)$ & .042 \\
\hline Women OSA10 $(n=82)$ & $3(5.4)$ & $18(32.1)$ & $35(62.5)$ & $3(11.5)$ & $12(46.2)$ & $11(42.3)$ & .20 \\
\hline \multicolumn{8}{|c|}{$\beta_{2}$ adrenergic receptor Gly16Arg and Gln27Glu $(n=157)$} \\
\hline Genotype (Gly16Arg) & $\mathrm{A} / \mathrm{A}$ & $\mathrm{A} / \mathrm{G}$ & G/G & $\mathrm{A} / \mathrm{A}$ & $\mathrm{A} / \mathrm{G}$ & G/G & $P$ \\
\hline Men OSA10 $(n=74)$ & $8(12.9)$ & $35(56.5)$ & $19(30.6)$ & $1(8.3)$ & $5(41.7)$ & $6(50.0)$ & .43 \\
\hline Women OSA10 $(n=83)$ & $8(14.0)$ & $22(38.6)$ & $27(47.4)$ & $4(15.4)$ & $13(50.0)$ & $9(34.6)$ & .54 \\
\hline Genotype (Gln27Glu) & $\mathrm{Gn} / \mathrm{Gn}$ & $\mathrm{Gn} / \mathrm{Gu}$ & $\mathrm{Gu} / \mathrm{Gu}$ & $\mathrm{Gn} / \mathrm{Gn}$ & $\mathrm{Gn} / \mathrm{Gu}$ & $\mathrm{Gu} / \mathrm{Gu}$ & $P$ \\
\hline Men OSA10 $(n=74)$ & $24(38.7)$ & $28(45.2)$ & $10(16.1)$ & $1(8.3)$ & $8(66.7)$ & $3(25.9)$ & .13 \\
\hline Women OSA10 $(n=83)$ & $17(29.8)$ & $27(47.4)$ & $13(22.8)$ & $10(38.5)$ & $10(38.5)$ & $6(23.1)$ & .70 \\
\hline $\mathrm{B}$ & & s with seve & & & without sev & & \\
\hline \multicolumn{8}{|c|}{$\alpha_{2 \mathrm{~B}}$-adrenergic receptor gene I/D polymorphism $(n=157)$} \\
\hline Genotype & & II & ID & DD & II & ID & $P$ \\
\hline Men OSA30 $(n=74)$ & $12(34.3)$ & $15(42.9)$ & $8(22.9)$ & $11(27.5)$ & $23(57.5)$ & $6(15.0)$ & .43 \\
\hline Women OSA30 $(n=83)$ & $8(36.4)$ & $12(54.6)$ & $2(9.1)$ & $21(35.0)$ & $26(43.3)$ & $13(21.7)$ & .40 \\
\hline \multicolumn{8}{|c|}{$\beta_{1}$ adrenergic receptor gene Ser49Gly and Gly389Arg polymorphisms $(n=156)$} \\
\hline Genotype (Ser49Gly) & $\mathrm{S} / \mathrm{S}$ & $\mathrm{S} / \mathrm{G}$ & G/G & $\mathrm{S} / \mathrm{S}$ & $\mathrm{S} / \mathrm{G}$ & G/G & $P$ \\
\hline Men OSA30 $(n=74)$ & $24(68.6)$ & $11(31.4)$ & $0(0.0)$ & $22(56.4)$ & $16(41.0)$ & $1(2.6)$ & .41 \\
\hline Women OSA30 $(n=82)$ & $15(68.2)$ & $5(22.7)$ & $2(9.1)$ & $44(73.3)$ & $13(21.7)$ & $3(5.0)$ & .78 \\
\hline Genotype (Gly389Arg) & $\mathrm{G} / \mathrm{G}$ & G/A & $\mathrm{A} / \mathrm{A}$ & $\mathrm{G} / \mathrm{G}$ & G/A & $\mathrm{A} / \mathrm{A}$ & $P$ \\
\hline Men OSA30 $(n=74)$ & $0(0.0)$ & $10(28.6)$ & $25(71.4)$ & $1(2.6)$ & $19(48.7)$ & $19(48.7)$ & .11 \\
\hline Women OSA30 $(n=82)$ & $2(9.1)$ & $7(31.8)$ & $13(59.1)$ & $4(6.7)$ & $23(38.3)$ & $33(55.0)$ & .83 \\
\hline \multicolumn{8}{|c|}{$\beta_{2}$-adrenergic receptor Gly16Arg and Gln27Glu $(n=157)$} \\
\hline Genotype (Gly16Arg) & $\mathrm{A} / \mathrm{A}$ & $\mathrm{A} / \mathrm{G}$ & G/G & $\mathrm{A} / \mathrm{A}$ & $\mathrm{A} / \mathrm{G}$ & $\mathrm{G} / \mathrm{G}$ & $P$ \\
\hline Men OSA30 $(n=74)$ & $2(5.7)$ & $22(62.9)$ & $11(31.4)$ & $7(18.0)$ & $18(46.2)$ & $14(35.9)$ & .19 \\
\hline Women OSA30 $(n=83)$ & $4(18.2)$ & $8(36.4)$ & $10(45.5)$ & $8(13.1)$ & $27(44.3)$ & $26(42.6)$ & .76 \\
\hline Genotype (Gln27Glu) & $\mathrm{Gn} / \mathrm{Gn}$ & $\mathrm{Gn} / \mathrm{Gu}$ & $\mathrm{Gu} / \mathrm{Gu}$ & $\mathrm{Gn} / \mathrm{Gn}$ & $\mathrm{Gn} / \mathrm{Gu}$ & $\mathrm{Gu} / \mathrm{Gu}$ & $P$ \\
\hline Men OSA30 $(n=74)$ & $11(31.4)$ & $19(54.3)$ & $5(14.3)$ & $14(35.9)$ & $17(43.6)$ & $8(20.5)$ & .62 \\
\hline Women OSA30 $(n=83)$ & $6(27.3)$ & $10(45.5)$ & $6(27.3)$ & $21(34.4)$ & $27(44.3)$ & $13(21.3)$ & .77 \\
\hline
\end{tabular}

OSA10: subjects dichotomised by AHI < or $\geq 10$ events/ hour; OSA30: subjects dichotomised by AHI $<$ or $\geq 30$ events/hour. $P$-values are estimated with chi2 test. A: (Arg) arginine; D: deletion; I: insertion; G: (Gly) Glycine; Gn:(Gln) Glutamine; Gu: (Glu) glutamic acid; S:(Ser) serine; HT: hypertensive; OSA: obstructive sleep apnoea.

chronotropic responses upon agonist binding. The Arg389 variant of the $\beta_{1}$-adrenergic receptor has been found to increase both the basal and the isoprotenerol-stimulated adenylate cyclase activity compared with the Gly389 variant. Experimental hypoxia in rats is a powerful activator of the sympathetic nervous system leading to increased blood pressure [48]. This is consistent with our results that a variant of the $\beta_{1}$-adrenergic receptor that confers an increased cyclic AMP activity and has been shown to be associated with hypertension also could be associated with increased risk of OSA in hypertensive patients. The gender difference found in this study could be due to the lower impact of the genetic variants of the sympathetic nervous system in development of OSA in females compared with males; instead anatomic factors in the throat might play a greater role in females [49]. The analysis of AHI in different $\beta_{1}$-adrenergic receptor genotype carriers showed a significant difference only in males. In fact we found no difference in AHI between 
TABLE 4: Differences in AHI between male and female carriers of the Arg389Gly genotypes of the Beta-1 adrenergic gene.

\begin{tabular}{|c|c|c|c|c|c|}
\hline \multirow[b]{2}{*}{ AHI (events per hour) } & \multicolumn{2}{|c|}{ Gly389Gly/Arg389Gly } & \multicolumn{2}{|c|}{ Arg389Arg } & \multirow[b]{2}{*}{$P$ (adjusted) } \\
\hline & Mean & $(\mathrm{SE})$ & Mean & $(\mathrm{SE})$ & \\
\hline Males & \multicolumn{2}{|c|}{$n=96$} & \multicolumn{2}{|c|}{$n=74$} & \\
\hline \multicolumn{6}{|l|}{ Normotensive subjects } \\
\hline (crude) & 20.5 & $(3.0)$ & 25.9 & $(2.9)$ & .20 \\
\hline (adjusted for age) & 20.1 & $(3.1)$ & 26.3 & $(2.9)$ & .15 \\
\hline (adjusted for age, BMI) & 20.5 & $(3.0)$ & 25.9 & $(2.8)$ & .20 \\
\hline \multicolumn{6}{|l|}{ Hypertensive patients } \\
\hline (crude) & 26.5 & $(4.6)$ & 39.5 & $(3.8)$ & .03 \\
\hline (adjusted for age) & 26.3 & $(4.6)$ & 39.6 & $(3.8)$ & .03 \\
\hline (adjusted for age, BMI) & 27.4 & $(4.5)$ & 38.6 & $(3.7)$ & .06 \\
\hline Females & \multicolumn{2}{|c|}{$n=85$} & \multicolumn{2}{|c|}{$n=82$} & \\
\hline \multicolumn{6}{|l|}{ Normotensive subjects } \\
\hline (crude) & 23.5 & $(4.1)$ & 21.3 & $(3.9)$ & .70 \\
\hline (adjusted for age) & 23.4 & (3.9) & 21.3 & $(3.8)$ & .70 \\
\hline (adjusted for age, BMI) & 22.8 & (3.7) & 21.9 & $(3.5)$ & .85 \\
\hline \multicolumn{6}{|l|}{ Hypertensive patients } \\
\hline (crude) & 24.4 & $(3.7)$ & 26.0 & $(3.3)$ & .76 \\
\hline (adjusted for age) & 23.9 & (3.6) & 26.3 & $(3.1)$ & .61 \\
\hline (adjusted for age, BMI) & 24.3 & (3.6) & 26.1 & $(3.1)$ & .71 \\
\hline
\end{tabular}

AHI: apnoea-hypopnoea index (events per hour). Data are mean (SE) and stepwise adjusted for age and age and BMI. One male hypertensive had missing BMI.

TABLE 5: Frequency of hypertension in patients with mild obstructive sleep apnea according to Beta-1 adrenergic receptor Arg389Gly polymorphism.

\begin{tabular}{lccc}
\hline Beta-1 adrenergic Genotype & Hypertension & Normotension & \\
\hline All $(n=229)$ & $n=118$ & $n=111$ & 9.9 \\
\hline Gly389Gly\% & 2.5 & 37.8 & \\
Gly389Arg\% & 34.8 & 52.3 & .043 \\
Arg389Arg\% & 62.7 & $n=62$ & 9.7 \\
\hline Males $(n=124)$ & $n=62$ & 37.1 & 53.2 \\
\hline Gly389Gly\% & 0 & 37.1 & .039 \\
Gly389Arg\% & 62.9 & & \\
Arg389Arg\%
\end{tabular}

$P$-values are estimated with chi-2 test.

female hypertensive patients and controls. This suggests that hypertension plays a less important role in OSA in women than in men. One limitation of this study is the small number of subjects especially after dichotomization into hypertension and normotension. In this particular polymorphism where the Gly389Gly genotype has a low frequency the data should be interpreted with care.

The polymorphisms in the other adrenergic receptor genes (the $\alpha_{2 \mathrm{~B}}$-adrenergic receptor and the $\beta_{2}$-adrenergic receptor) were not associated with OSA in this study population.

The $\alpha_{2 \mathrm{~B}}$-adrenergic receptor gene I/D 301-303 polymorphism studied here is proposed to influence the agonistinduced desensitization of the receptor. We found no association between this polymorphism and OSA in hypertensive or normotensive individuals. One explanation might be that the $\alpha_{2 \mathrm{~B}}$-adrenergic receptor acts on a level of sympathetic action that is only indirectly involved in the adrenergic response of the heart to hypoxia induced during OSA.

The lack of association between polymorphisms of the $\beta_{2}$-adrenergic receptor and OSA is in accordance with the results from a cohort with high prevalence of hypertension from Germany [50] although the risk of myocardial infarctions was associated with the polymorphisms. Furthermore, these polymorphisms have been shown to be associated with hypertension only in the presence of type 2 diabetes in the current population [35]. Compared to the $\beta_{1}$-adrenergic receptor the $\beta_{2}$-adrenergic receptor has a similar but less pronounced effect in the heart. This difference in action could explain why the $\beta_{2}$-polymorphisms investigated here do not seem to be of importance in development of OSA in hypertensive patients. 
In conclusion, the Arg389Gly polymorphism of the $\beta_{1}$ adrenergic receptor was associated with increased risk of OSA in hypertensive men and with hypertension in subjects with mild OSA. Also, in men, there was a dose dependent increase in AHI being the lowest in Gly389Gly carriers and the highest in Arg389Arg carriers. These findings highlight the role of the sympathetic nervous system in OSA and hypertension.

\section{Acknowledgments}

This research was funded by Swedish Medical Research Council, Swedish Heart Lung Foundation, the Sahlgrenska University Hospital funds, the Skaraborg Institute, Skaraborg Primary Care, Health and Medical Care Executive Board of the Region Västra Götaland, the Region Skåne, the Faculty of Medicine, Lund University, and the NEPI Foundation (The Swedish Network of Pharmacoepidemiology). The authors are most grateful to Mrs. Ann Segerblom, Mrs. Anita Mehner and Mrs. Lena Nilsson for excellent technical assistance.

\section{References}

[1] J. C. T. Pepperell, R. J. O. Davies, and J. R. Stradling, "Systemic hypertension and obstructive sleep apnoea," Sleep Medicine Reviews, vol. 6, no. 3, pp. 157-173, 2002.

[2] J. T. Carlson, J. Hedner, M. Elam, H. Ejnell, J. Sellgren, and B. G. Wallin, "Augmented resting sympathetic activity in awake patients with obstructive sleep apnea," Chest, vol. 103, no. 6, pp. 1763-1768, 1993.

[3] J. S. Loredo, M. G. Ziegler, S. Ancoli-Israel, J. L. Clausen, and J. E. Dimsdale, "Relationship of arousals from sleep to sympathetic nervous system activity and BP in obstructive sleep apnea," Chest, vol. 116, no. 3, pp. 655-659, 1999.

[4] E. C. Fletcher, G. Bao, and R. Li, "Renin activity and blood pressure in response to chronic episodic hypoxia," Hypertension, vol. 34, no. 2, pp. 309-314, 1999.

[5] A. B. Newman, F. J. Nieto, U. Guidry, et al., "Relation of sleepdisordered breathing to cardiovascular disease risk factors: the Sleep Heart Health Study," American Journal of Epidemiology, vol. 154, no. 1, pp. 50-59, 2001.

[6] P. E. Peppard, T. Young, M. Palta, and J. Skatrud, "Prospective study of the association between sleep-disordered breathing and hypertension," New England Journal of Medicine, vol. 342, no. 19 , pp. 1378-1384, 2000.

[7] J. Hedner, K. Bengtsson-Boström, Y. Peker, L. Grote, L. Råstam, and U. Lindblad, "Hypertension prevalence in obstructive sleep apnoea and sex: a population-based casecontrol study," European Respiratory Journal, vol. 27, no. 3, pp. 564-570, 2006.

[8] F. J. Nieto, T. B. Young, B. K. Lind, et al., "Association of sleepdisordered breathing sleep apnea, and hypertension in a large community-based study," Journal of the American Medical Association, vol. 283, no. 14, pp. 1829-1836, 2000.

[9] E. Shahar, C. W. Whitney, S. Redline, et al., "Sleep-disordered breathing and cardiovascular disease: cross-sectional results of the Sleep Heart Health Study," American Journal of Respiratory and Critical Care Medicine, vol. 163, no. 1, pp. 19-25, 2001.

[10] I. Gavras, A. J. Manolis, and H. Gavras, "The $\alpha 2$-adrenergic receptors in hypertension and heart failure: experimental and clinical studies," Journal of Hypertension, vol. 19, no. 12, pp. 2115-2124, 2001.
[11] F. von Wowern, K. Bengtsson, C. M. Lindgren, et al., "A genome wide scan for early onset primary hypertension in Scandinavians," Human Molecular Genetics, vol. 12, no. 16, pp. 2077-2081, 2003.

[12] T. Rice, T. Rankinen, M. A. Province, et al., "Genome-wide linkage analysis of systolic and diastolic blood pressure: the Québec Family Study," Circulation, vol. 102, no. 16, pp. 19561963, 2000.

[13] M. Perola, K. Kainulainen, P. Pajukanta, et al., "Genome-wide scan of predisposing loci for increased diastolic blood pressure in Finnish siblings," Journal of Hypertension, vol. 18, no. 11, pp. 1579-1585, 2000.

[14] K. Kristjansson, A. Manolescu, A. Kristinsson, et al., "Linkage of essential hypertension to chromosome 18q," Hypertension, vol. 39, no. 6, pp. 1044-1049, 2002.

[15] N. Suzuki, T. Matsunaga, K. Nagasumi, et al., " $\alpha 2 b$-Adrenergic receptor deletion polymorphism associates with autonomic nervous system activity in young healthy Japanese," Journal of Clinical Endocrinology and Metabolism, vol. 88, no. 3, pp. 1184-1187, 2003.

[16] F. Von Wowern, K. Bengtsson, U. Lindblad, et al., "Functional variant in the $\alpha 2 \mathrm{~B}$ adrenoceptor gene, a positional candidate on chromosome 2, associates with hypertension," Hypertension, vol. 43, no. 3, pp. 592-597, 2004.

[17] R. Vasudevan, P. Ismail, J. Stanslas, N. Shamsudin, and A. B. Ali, "Association of insertion/deletion polymorphism of alpha-adrenoceptor gene in essential hypertension with or without type 2 diabetes mellitus in Malaysian subjects," International Journal of Biological Sciences, vol. 4, no. 6, pp. 362-367, 2008.

[18] C. D. Strader, T. M. Fong, M. R. Tota, D. Underwood, and R. A. F. Dixon, "Structure and function of G protein-coupled receptors," Annual Review of Biochemistry, vol. 63, pp. 101132,1994

[19] K. Ranade, E. Jorgenson, W. H.-H. Sheu, et al., "A polymorphism in the $\beta 1$ adrenergic receptor is associated with resting heart rate," American Journal of Human Genetics, vol. 70, no. 4, pp. 935-942, 2002.

[20] D. A. Mason, J. D. Moore, S. A. Green, and S. B. Liggett, "A gain-of-function polymorphism in a G-protein coupling domain of the human $\beta_{1}$-adrenergic receptor," Journal of Biological Chemistry, vol. 274, no. 18, pp. 12670-12674, 1999.

[21] K. Bengtsson, O. Melander, M. Orho-Melander, et al., "Polymorphism in the $\beta 1$-adrenergic receptor gene and hypertension," Circulation, vol. 104, no. 2, pp. 187-190, 2001.

[22] A. P. Gjesing, G. Andersen, A. Albrechtsen, et al., "Studies of associations between the Arg389Gly polymorphism of the $\beta_{1}$-adrenergic receptor gene (ADRB1) and hypertension and obesity in 7677 Danish white subjects," Diabetic Medicine, vol. 24, no. 4, pp. 392-397, 2007.

[23] G. G. Sofowora, V. Dishy, M. Muszkat, et al., "A common $\beta 1$ adrencrgic receptor polymorphism (Arg389Gly) affects blood pressure response to $\beta$-blockade," Clinical Pharmacology and Therapeutics, vol. 73, no. 4, pp. 366-371, 2003.

[24] J. A. Johnson, I. Zineh, B. J. Puckett, S. P. McGorray, H. N. Yarandi, and D. F. Pauly, " $\beta_{1}$-adrenergic receptor polymorphisms and antihypertensive response to metoprolol," Clinical Pharmacology and Therapeutics, vol. 74, no. 1, pp. 44-52, 2003.

[25] H. L. White, A. Maqbool, A. D. McMahon, et al., "An evaluation of the beta-1 adrenergic receptor Arg389Gly polymorphism in individuals at risk of coronary events. A WOSCOPS substudy," European Heart Journal, vol. 23, no. 14, pp. 1087-1092, 2002. 
[26] C. Iwai, H. Akita, K. Kanazawa, et al., "Arg389Gly polymorphism of the human $\beta_{1}$-adrenergic receptor in patients with nonfatal acute myocardial infarction," American Heart Journal, vol. 146, no. 1, pp. 106-109, 2003.

[27] J. Börgel, T. Schulz, N. K. Bartels, et al., "Modifying effects of the R389G $\beta_{1}$-adrenoceptor polymorphism on resting heart rate and blood pressure in patients with obstructive sleep apnoea," Clinical Science, vol. 110, no. 1, pp. 117-123, 2006.

[28] L. P. Svetkey, P. Z. Timmons, O. Emovon, N. B. Anderson, L. Preis, and Y.-T. Chen, "Association of hypertension with $\mathrm{B}_{2}$ and $\mathrm{A}_{2 \mathrm{c} 10}$-adrenergic receptor genotype," Hypertension, vol. 27, no. 6, pp. $1210-1215,1996$.

[29] J. Krushkal, M. Xiong, R. Ferrell, C. F. Sing, S. T. Turner, and E. Boerwinkle, "Linkage and association of adrenergic and dopamine receptor genes in the distal portion of the long arm of chromosome 5 with systolic blood pressure variation," Human Molecular Genetics, vol. 7, no. 9, pp. 1379-1383, 1998.

[30] M. S. Bray, J. Krushkal, L. Li, et al., "Positional genomic analysis identifies the $\beta_{2}$-adrenergic receptor gene as a susceptibility locus for human hypertension," Circulation, vol. 101, no. 25, pp. 2877-2882, 2000.

[31] S. Liggett, "Functional properties of human $\beta_{2}$-adrenergic receptor polymorphisms," The Neural Information Processing Systems, vol. 10, pp. 265-273, 1995.

[32] M. Castellano, F. Rossi, M. Giacchè, et al., " $\beta_{2}$-adrenergic receptor gene polymorphism, age, and cardiovascular phenotypes," Hypertension, vol. 41, no. 2, pp. 361-367, 2003.

[33] S.-M. Herrmann, V. Nicaud, L. Tiret, et al., "Polymorphisms of the $\beta_{2}$-adrenoceptor (ADRB2) gene and essential hypertension: the ECTIM and PEGASE studies," Journal of Hypertension, vol. 20, no. 2, pp. 229-235, 2002.

[34] B. Timmermann, R. Mo, F. C. Luft, et al., " $\beta-2$ adrenoceptor genetic variation is associated with genetic predisposition to essential hypertension: the Bergen Blood Pressure Study," Kidney International, vol. 53, no. 6, pp. 1455-1460, 1998.

[35] K. Bengtsson, M. Orho-Melander, O. Melander, et al., “ $\beta_{2}$ adrenergic receptor gene variation and hypertension in subjects with type 2 diabetes," Hypertension, vol. 37, no. 5, pp. 1303-1308, 2001.

[36] E. Bøg-Hansen, U. Lindblad, K. Bengtsson, J. Ranstam, A. Melander, and L. Råstam, "Risk factor clustering in patients with hypertension and non-insulin- dependent diabetes mellitus. The Skaraborg Hypertension Project," Journal of Internal Medicine, vol. 243, no. 3, pp. 223-232, 1998.

[37] K. Bengtsson, M. Orho-Melander, U. Lindblad, et al., "Polymorphism in the angiotensin converting enzyme but not in the angiotensinogen gene is associated with hypertension and type 2 diabetes: the Skaraborg Hypertension and Diabetes Project," Journal of Hypertension, vol. 17, no. 11, pp. 15691575, 1999.

[38] Treatment of Mild Hypertension, vol. 1, National Board of Health and Welfare, Drug Information Committee, Stockholm, Sweden, 1987.

[39] Treatment of Hypertension in the Elderly, Information from Medical Products Agency, Stockholm, Sweden, 1993.

[40] Guidelines Sub-Committee, "Guidelines for the management of mild hypertension: memorandum from a World Health Organization/International Society of Hypertension meeting," Journal of Hypertension, vol. 7, pp. 689-693, 1989.

[41] WHO Study Group, Diabetes Mellitus, World Health Organization, Geneva, Switzerland, 1985.

[42] G. A. Rose, H. Blackburn, R. F. Gillum, et al., Cardiovascular Survey Methods, World Health Organization, Geneva, Switzerland, 2nd edition, 1982.
[43] L. Råstam and G. Sjönell, "A new device for measuring blood pressure in adults," Lancet, vol. 337, no. 8735, pp. 249-250, 1991.

[44] T. Gislason, M. Almqvist, G. Eriksson, A. Taube, and G. Boman, "Prevalence of sleep apnea syndrome among Swedish men-an epidemiological study," Journal of Clinical Epidemiology, vol. 41, no. 6, pp. 571-576, 1988.

[45] A. Rechtschaffen and A. Kales, A Manual of Standardized Terminology, Techniques, and Scoring System for Sleep Stages of Human Subjects, UCLA Brain Information Service/Brain Research Institute, Los Angeles, Calif, USA, 1968.

[46] S. Vandenplas, I. Wiid, and A. Grobler-Rabie, "Blot hybridisation analysis of genomic DNA," Journal of Medical Genetics, vol. 21, no. 3, pp. 164-172, 1984.

[47] A. Maqbool, A. S. Hall, S. G. Ball, and A. J. Balmforth, "Common polymorphisms of $\beta_{1}$-adrenoceptor: identification and rapid screening assay," Lancet, vol. 353, no. 9156, p. 897, 1999.

[48] G. Bao, N. Metreveli, R. Li, A. Taylor, and E. C. Fletcher, "Blood pressure response to chronic episodic hypoxia: role of the sympathetic nervous system," Journal of Applied Physiology, vol. 83, no. 1, pp. 95-101, 1997.

[49] S. G. Buxbaum, R. C. Elston, P. V. Tishler, and S. Redline, "Genetics of the apnea hypopnea index in Caucasians and African Americans: I. Segregation analysis," Genetic Epidemiology, vol. 22, no. 3, pp. 243-253, 2002.

[50] N. K. Bartels, J. Börgel, S. Wieczorek, et al., "Risk factors and myocardial infarction in patients with obstructive sleep apnea: impact of $\beta_{2}$-adrenergic receptor polymorphisms," BMC Medicine, vol. 5, article 1, 2007. 


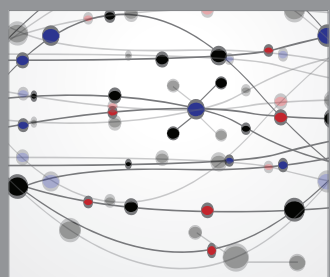

The Scientific World Journal
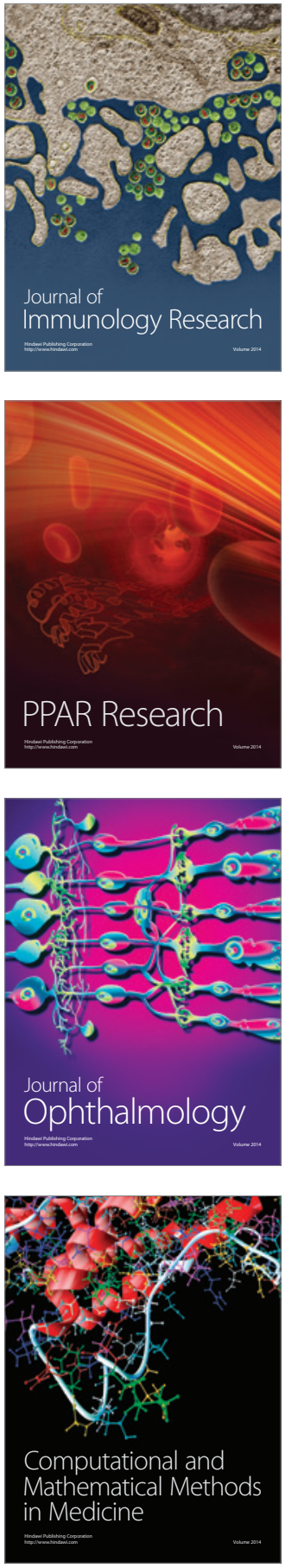

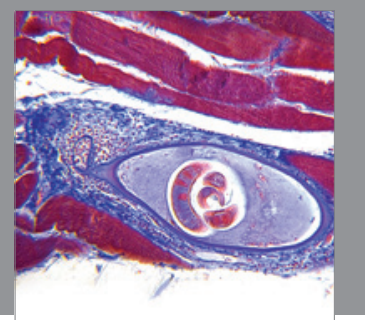

Gastroenterology

Research and Practice
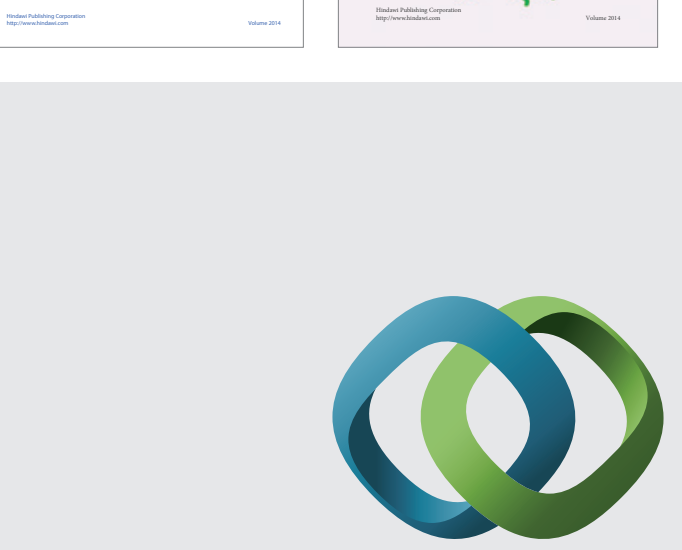

\section{Hindawi}

Submit your manuscripts at

http://www.hindawi.com
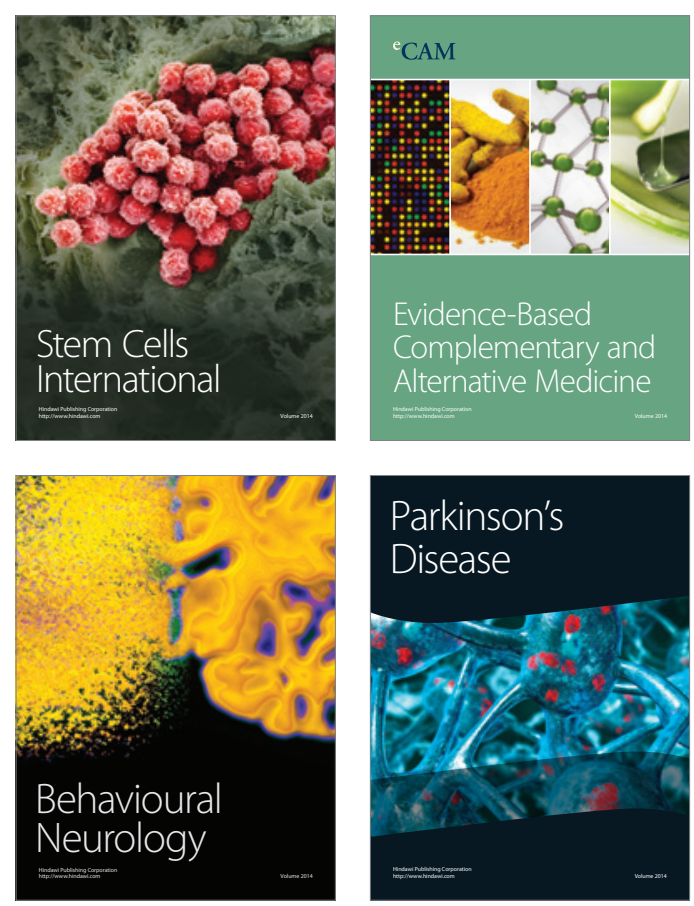

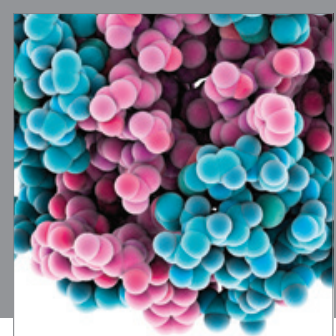

Journal of
Diabetes Research

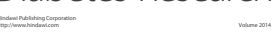

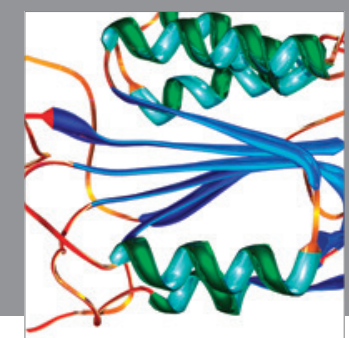

Disease Markers
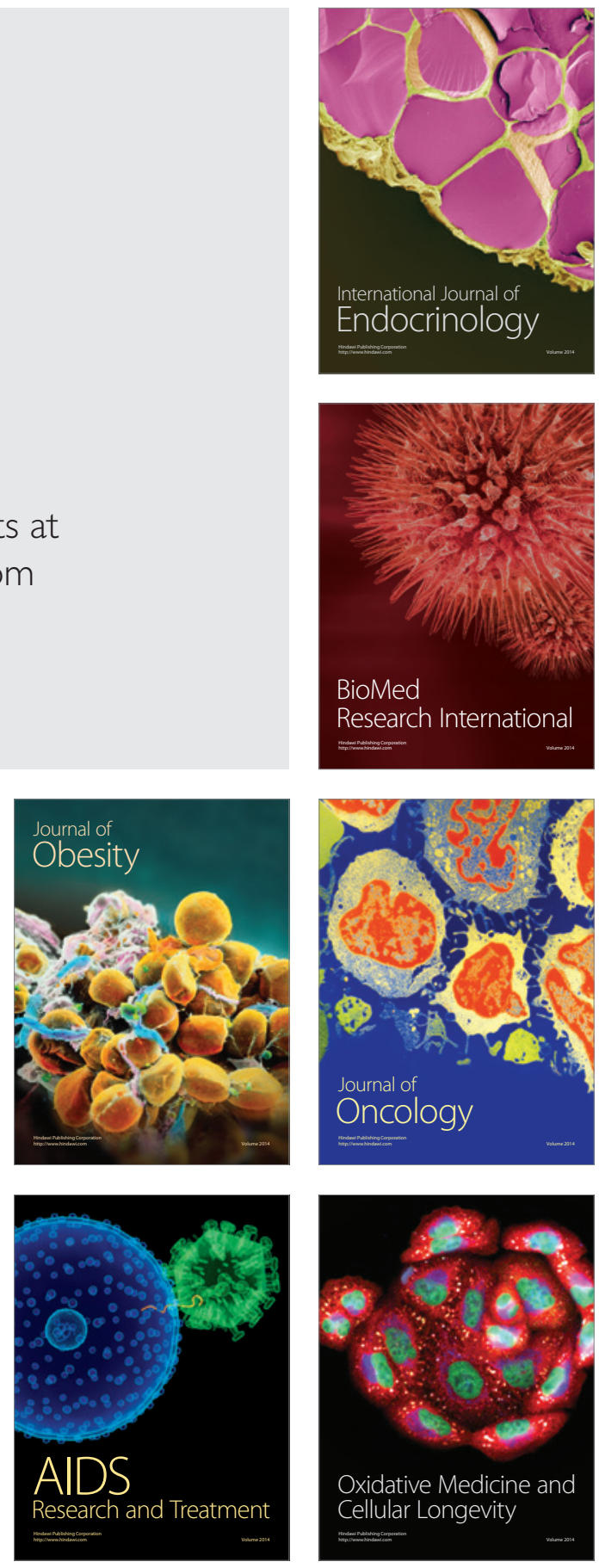